\title{
Indigenous Fire Management in the cerrado of Brazil: The Case of the Krahô of Tocantíns
}

\author{
Jayalaxshmi Mistry, ${ }^{1,5}$ Andrea Berardi, ${ }^{2}$ Valeria Andrade, ${ }^{3}$ \\ Txicaprô Krahô, ${ }^{4}$ Phocrok Krahô, ${ }^{4}$ and Othon Leonardos ${ }^{3}$
}

Indigenous peoples have been using fire in the cerrado (savannas) of Brazil as a form of management for thousands of years, yet we have little information on why, when and how these fire practices take place. The aim of this paper was to explore the traditional use of fire as a management tool by the Krahô indigenous group living in the north-eastern region of Tocantins state, Brazil. The results indicate that the Krahô burn for a variety of reasons throughout the dry season, thereby producing a mosaic of burned and unburned patches in the landscape. The paper discusses this burning regime in the context of contemporary issues regarding fire management, and in the face of changing perceptions to fire by the Krahô themselves.

KEY WORDS: savanna; cerrado; Brazil; indigenous fire management; patch dynamics.

\section{INTRODUCTION}

Fire is a major determinant of the savannas (cerrado) of Brazil. Wildfires have been significant in the cerrado for thousands of years, shaping the landscape and its biotic components since at least the Middle

${ }^{1}$ Department of Geography, Royal Holloway, University of London, Egham, Surrey, United Kingdom.

${ }^{2}$ Open Systems Research Group, Faculty of Technology, The Open University, Walton Hall, Milton Keynes, United Kingdom.

${ }^{3}$ Centro de Desenvolvimento Sustentavel (CDS), Universidade de Brasilia, Brasilia D.F., Brazil.

${ }^{4}$ Aldeia Manuel Alves, Território Krahô, Tocantíns, Brazil.

${ }^{5}$ To whom correspondences should be addressed at Department of Geography, Royal Holloway, University of London, Egham, Surrey TW20 0EX, United Kingdom; e-mail: j.mistry@rhul.ac.uk. 
Holocene, some 6000 years B.P. (Miranda et al., 2002; Vernet et al., 1994). However, it was the "second fire" (Pyne, 2001) i.e., humans, that changed the nature of wildfires, increasing fire frequency and behavior. Indigenous people have occupied the cerrado from between 35,000 and 15,000 years ago (Lavallée, 1995; Watanabe et al., 2003), and probably used fire to manipulate the landscape and its resources at various times of the year. However, anthropogenic fires became more prominent some 10,000 years ago, as the indigenous population spread out, the climate became more seasonal, and the cerrado we see today became established towards the midHolocene (Barbosa, 2002; Behling, 1998; Salgado-Labouriau et al., 1998). Charcoal deposits found in palaeoenvironmental studies indicate that fire was increasingly employed throughout the Holocene (Alexandre et al., 1999; Barberi et al., 2000; Behling, 1995, 2002).

Data on human use of fire in the cerrado are scarce, and some are anecdotal evidence from various anthropological studies on indigenous people. Indigenous tribes use fire for hunting, and as signals to other tribes (Lukesch, 1969; Maybury-Lewis, 1984; Nimuendajú, 1983; Villas-Boas and Villas-Boas, 1976). Anderson and Posey $(1985,1989)$ observed that the Kayapó people burn the cerrado for its aesthetic quality, to reduce populations of snakes and scorpions, and to facilitate walking through the vegetation. According to them, tribal elders determined the time for the burns using astrological, meteorological, and ecological indicators. One temporal marker was the flowering of the pequí tree (Caryocar brasiliense), a key resource for the Indians. Some burns were effectively controlled: precautionary firebreaks were constructed by removing dry grass and shrubs, and during the fire branches were employed to avoid fires penetrating other areas.

Fire is a powerful tool available to modify soil properties, and is especially useful for forming and managing swidden plots (termed roça in Portuguese). Hecht and Posey (1989) for example, document the burning of swidden plots of the Kayapó throughout the cultivation cycle, emphasising the importance of ash for land management, as well as other ritual and medicinal functions. Balée (1994) describes swidden burning of the Ka'apor: several men from different households space themselves at one end of the plot, ignite their shredded bundles of bark and kindling, and move in a zigzag formation across the area to ensure an even burn. The Kayapó also carry out crop and pest specific burning after some crops have been planted, for example, spot fires to control the sweet potato virus disease (Kerr and Posey, 1984).

Linguistic studies have indicated a rich vocabulary of "fire" words in cerrado tribes such as the Kayapó and Xavante (Giaccaria and Heide, 1984; Hall et al., 1987; McLeod and Mitchell, 1980). This all suggests that fire has an important role to play in indigenous lives. Yet we know little about the 
burning regime of indigenous people, although understanding traditional burning practices may help us with contemporary issues regarding fire management. With this in mind, the present paper explores the traditional use of fire as a management tool by the Krahô, an indigenous group living in the north-eastern region of Tocantíns state, Brazil.

\section{STUDY SITE}

The Krahô indigenous reserve is located approximately 100 km northeast of Palmas, situated within the municipalities of Goiatins and Itacajá, near the Tocantíns-Maranhão border (Fig. 1). It covers an area of roughly $3200 \mathrm{~km}^{2}$, between the rivers Manuel Alves and Vermelho, and is home to 16 villages of various sizes, totalling approximately 2000 individuals. The climate is distinctly seasonal, characterized by a rainy season that begins around early October and ends in April. The average annual rainfall varies between 1600 and $1800 \mathrm{~mm}$, with approximately $75 \%$ falling during the rainy season. The subsequent dry and fire season normally runs from May through to September. The landscape is characterized by Palaeozoic sandstone tablelands, which are the source of various waterways within and outside the reserve. The vegetation is dominated by cerrado sensu lato (a series of vegetation physiognomies from open grasslands to dense woodlands, after Oliveira-Filho and Ratter, 2002) under a quartzose sandy soil and minor clayish patches derived from black shale lenses; a mosaic of vegetation types are present throughout the reserve, including evergreen and riparian forests, grassland and vereda (marshland dominated by grassland and buriti palm trees (Mauritia vinifera)). The reserve is virtually an island, surrounded by large farms where most of the natural vegetation has been removed and replaced with exotic (African) pasture grasses for cattle raising.

\section{METHODS}

The Krahô are a subgroup of the Timbira linguistic family (Melatti, 1986). Their first contact with non-indigenous people was during the time of cattle raising expansion at the beginning of the eighteenth century (Melatti, 1972). Originally seminomadic, they had a series of violent clashes with nonindigenous people until the area in which they live today was demarcated for them in 1944. Similar to the more studied Kayapó (see Posey, 1998) and Ka'apor groups (see Balée, 1994), the Krahó are hunters, gatherers, and shifting cultivators, living in a savanna-forest environment. 


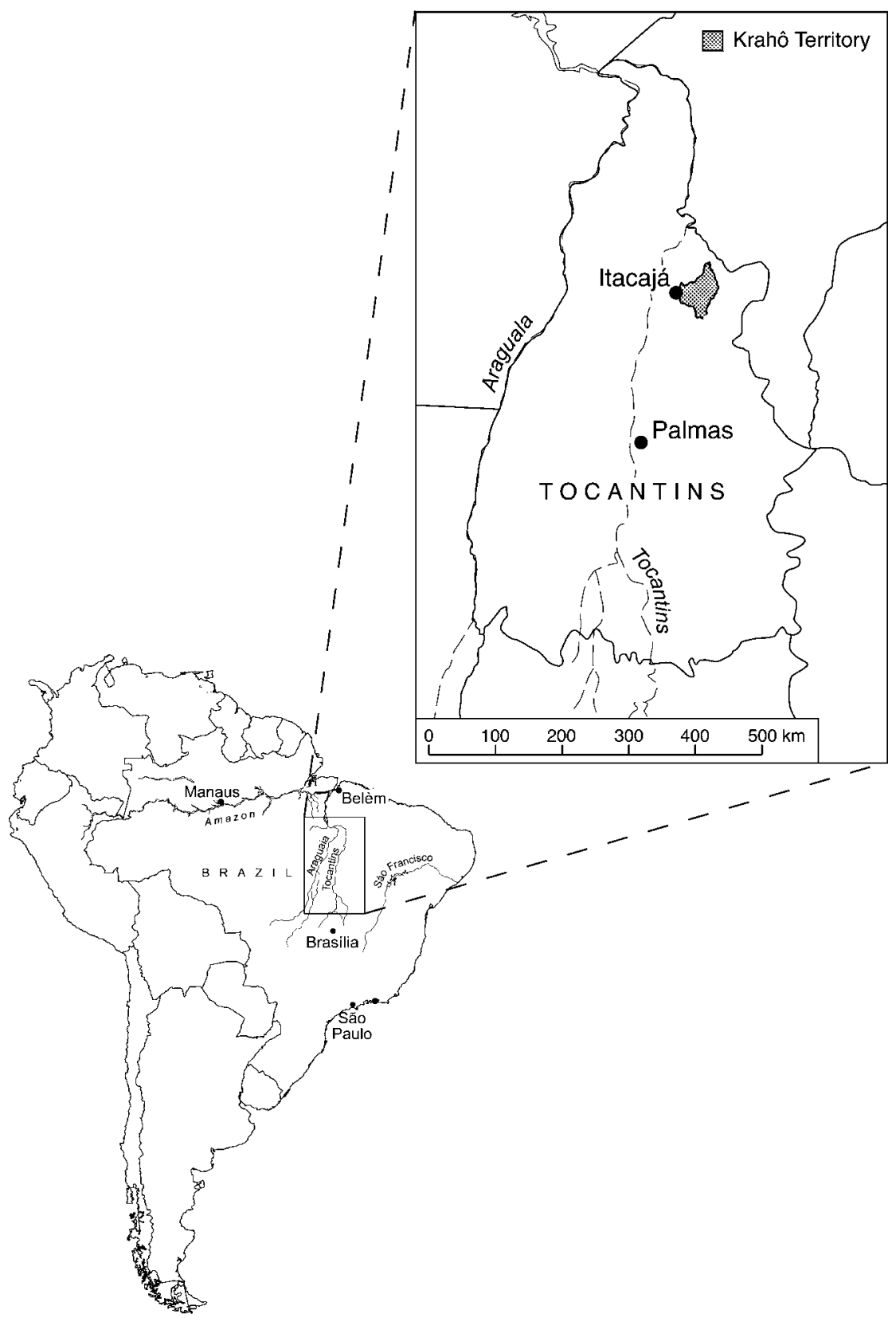

Fig. 1. Location of the Krahô reserve in the state of Tocantíns, Brazil. Drawn by Jenny Kynaston. 
Of the 16 villages in the reserve, five were the focus of this study: Manuel Alves, Santa Cruz, Morro do Boi, Campo Limpo, and Pedra Branca. Previous contact over a number of years had been made with these villages by the Brazilian members of the research team, making it easier to carry out the study. These villages were also the most accessible in terms of the time available. The proposed research was discussed with the villages prior to the project being started by FUNAI (the government body in charge of Amerindian affairs) outreach workers, and permission was sought and granted, both from the villages themselves and FUNAI. Work was carried out in collaboration with two Krahô villagers, Txicaprô Krahô and Phocrok Krahô, both from the village of Manuel Alves and both with family in the other villages. The data presented here were recorded in field notes and on videotape, in collaboration with a number of older Krahô villagers.

Fieldwork took place over 2 months in the late dry season months of August and September. In depth semistructured (and open) interviews were conducted with the villagers either individually or in groups (Dawson et al., 1993; Krueger, 1994; Levy and Hollan, 1998). They were asked openended questions pertaining to the burning regime, the reasons for burning, the history of land use, and their perceptions of fire. Most Krahô men speak Portuguese, but in some cases it was necessary to translate questions and let the villagers explain in their own Krahô language (part of the Jê group). Interpreting indigenous ideas and concepts can be problematic especially when translating from different languages (Posey, 1992), so careful documentation, checking, and cross-checking took place. Nevertheless, there were some words the translators found difficult to translate from Krahô into Portuguese, so it is inevitable that some material may have been lost. Focus group interviews took place with male members of the villages, as the somewhat patriarchal nature of Krahô society meant that women did not participate in formal meetings with outsiders, save in Santa Cruz village which is run under female leadership. One-to-one interviews were carried out with women by the female members of our research team.

In order to aid our understanding of the interview material, the research team also participated with Krahô villagers in some of their fire management activities (Dewalt et al., 1998; Geertz, 1983). Approximately 20 extended walks ranging from $30 \mathrm{~min}$ to $4 \mathrm{~h}$ with villagers allowed us to observe hunting, gathering, cultivation, ceremonial burning practices and the environmental determinants of the landscape.

\section{RESULTS}

The Krahô are divided into two functional groupings: Wakmejê (summer, dry season, sun, east group); and Katamjê (winter, rainy season, moon, 
west group). Group membership is not differentiated by gender and is determined by the alliance between a child and one of his or her uncles or aunts respectively. The child adopts the relative's four names and their group membership.

The two groups are identified separately by body paints, and form the basis of everyday activities as well as social rules. For example, twice every day throughout the year, the villagers compete against each other in the "krow" or "corrida de toras" running with a (buriti [Mauritia vinifera] palm $\log$ ). The race begins in the surrounding cerrado, and the tora is relayed between members of the same group to the village and around it. Group members also hunt together. Conversely, marriage must be between persons belonging to opposite groups for the couple to "get on." However, maybe most importantly, decision-making control is cycled between the male members of the groups depending on the season. Although male control is apparent, male action must be in accordance with the wishes of spouses.

\section{Decision-Making Amongst the Krahô}

During the dry season (May to September), the Wakmejê men have control over decision-making, while during the rainy season (October to April), the Katamjê men are the decision makers, allowing each group to control certain activities. For example, during the rainy season, the Katamjê "command" activities such as planting, while the Wakmejê command 'kô' or fire. Thus, the Wakmejê are deemed the holders of fire knowledge; they are the ones who decide on certain aspects of the fire burning regime. Conversely, the Katamjê are not regarded as having inherent fire management knowledge. The procedures for decision-making are relatively straightforward. Every morning at sunrise, the men meet at the centre of the village (the $\mathrm{ka}$ ) to discuss the day's activities, and depending on the season, the relevant group decides on the course of action.

Fire knowledge is transmitted through observation and practice. Younger members of the community and even children accompany older members in fire management activities. Throughout our fieldwork we observed no conventional teacher-student relationship between generations and rarely witnessed punishment when children "misbehaved." Younger generations learn from observation and participation in daily activities, where the rewards were usually immediate (food to eat, shelter, etc.). We did observe conflict among adults, where disagreement was communicated through loud chanting that often went on through the night. Conflicts were usually settled by "payment" to the injured party of material goods or, in extreme cases, the expulsion of the offending individual from the village. 
Table I. The Main Reasons for Burning as Identified by the Krahô

\begin{tabular}{ll}
\hline & Reasons for burning \\
\hline Cultivation & Land clearing and preparation \\
& Nutrient enrichment from ash \\
Hunting & Fires to attract game "Fire drive" \\
Harvesting natural resources & Fruits stimulated by fire \\
& Honey extraction \\
Aesthetic reasons & Keep clean, increase visibility in vegetation and \\
& landscape \\
Protection & Fires for protection of roça \\
& Fires for protection of certain fruiting trees \\
& Fires to protect areas of cerrado from later, more \\
& intense fires \\
& Fires to protect "carrasco," areas of cerrado vegetation \\
& which are perceived to contain many animals and \\
& fruiting trees. \\
Livestock grazing & Fires to promote grass re-growth \\
Eliminate pests & Kill snakes and insects \\
Outsider fires & Fires caused by poachers entering reserve, or from \\
& farmers living on periphery \\
\hline
\end{tabular}

\section{Fire Use and Management by the Krahô}

The burning regime of the Krahô takes place between April and late September at a range of distances from the settlements, and for a variety of reasons (Tables I and II). Burning takes place throughout the dry season, forming a mosaic of burns. There is a differentiation in burning practices according to whether they are under the control of the Wakmejê group or under the control of the individual.

\section{Burning Determined by the Wakmejê}

Burning determined by the Wakmejê can be divided into three categories: protective, resource enhancing, and game driving.

Protective burning is principally centred around the swidden plots. As soon as fuels begin to cure in the early dry season (mid-April/May), lowintensity fires are set around the plots and the adjoining gallery forest so as to create a buffer from high intensity late-season fires. A thicket-forming type of cerrado, termed "carrasco," is also protected by early dry season burns as it is rich in fruiting trees as well as many animals and consequently a potential hunting ground. To enhance hunting potential, when fires are set in early to mid-dry season, they are positioned near inaccessible areas of vegetation to promote the resprouting of grasses that may attract game. Areas of carrasco are protected from extractive activities for 5-6 years, 
Table II. The Different Burning Regimes Used by the Krahô

\begin{tabular}{|c|c|}
\hline \multicolumn{2}{|c|}{ Burning regimes for different purposes } \\
\hline Protection of roça & Early dry season, around April/May \\
\hline Protection of certain fruiting trees & Early dry season, around April/May \\
\hline Hunting & $\begin{array}{l}\text { April is perceived as the best time-small } \\
\text { patches of cerrado are burnt over a number of } \\
\text { days during a hunting trip }\end{array}$ \\
\hline Protection of carrasco & Burnt April/May every 5-6 years \\
\hline Livestock grazing & $\begin{array}{l}\text { Pasture burnt in mid-May-small areas burnt } \\
\text { each year }\end{array}$ \\
\hline $\begin{array}{l}\text { Protection of areas of cerrado } \\
\text { from later, more intense fires }\end{array}$ & Early to mid dry season \\
\hline $\begin{array}{l}\text { Clearing and preparing land for } \\
\text { planting }\end{array}$ & $\begin{array}{l}\text { Roças are burnt at the very end of August or in } \\
\text { September }\end{array}$ \\
\hline Honey extraction & September and October \\
\hline Keep clean and increase visibility & $\begin{array}{l}\text { Throughout the dry season-fires are set when } \\
\text { walking to villages, hunting and travelling to } \\
\text { roças }\end{array}$ \\
\hline Eliminate pests & Throughout dry season \\
\hline Outsider fires & Occur throughout dry season \\
\hline
\end{tabular}

during which time the peripheries are burned for protection from other cerrado fires.

Resource enhancing fires are set to stimulate fruiting and fresh grass. Areas that have a particularly high density of fruiting trees (see Table III) are burned in the early dry season, normally April or May, to promote flowering and the consequent production of fruit. These are a crucial component of Krahô nutrition during the dry season. We observed Mangaba (Hancornia spp.) trees whose surroundings had been burned in the early dry season and were laden with fruit, and trees of the same species whose surroundings had not been burned and had very little fruit on them.

Table III. Some Fruiting Trees Identified by the Krahô to be Protected or Enhanced by Early Season Fires (Common Name, Scientific name, Krahô Name)

\begin{tabular}{l}
\hline \multicolumn{1}{c}{ Some fruiting trees protected by fire } \\
\hline Babaçu (Orbygnia cf. phalerata) \\
Bacaba (Oenocarpus bacaba) Mart., capêr, cààpêr \\
Buriti (Maurita vinifera), krow \\
Caju (Anacardium spp.), akrôt ró, ahkrytre \\
Coquinho-do-cerrado (Syagrus flexuosa) \\
Jatobá (Hymenaea stigonocarpa), poiconré, pôjkôre, poikok \\
Mangaba (Hancornia spp.), apem \\
Marmelada (Alibertia spp.), huioré, hujore \\
Pequi (Caryocar brasiliensis), prim \\
Puçá (Mouriri pusa)
\end{tabular}


Fire is also used to drive game into open areas. Hunting is carried out by men, usually with guns, bows and arrows, sling-shots, and traps. Trips are organized where some 20 men will leave the village for a couple of weeks to hunt further afield. Prey includes deer, anteaters, birds, tortoises, and other small mammals. Some animals are also hunted for their noncomestible/ornamental value (deer hooves and skins, parrot feathers). Various villagers commented that the early dry season was a good time to burn the cerrado for hunting purposes, particularly for deer. In this case, a large area surrounded with natural barriers (hills and streams) is selected, and different points in the area of cerrado are ignited simultaneously leaving only one escape route where the hunters wait and kill the deer as they try to escape the fire. Another version of this practice is to encircle the prey with fire and let the fire do the killing. Because the combustible fuel is still moist, fires in April are easily controllable and do not spread to the forest. These types of fires are also set in May, June, and July, but become dangerous in August and September.

\section{Burnings Determined by the Individual}

Burning practices determined by the individual include clearing and sterilizing an area for cultivation, honey collection, livestock grazing, and "cleaning" the cerrado.

Cultivation is carried out in swidden plots (roças) within gallery forests, which may be within several hours or a day's walking distance from the village. It is usually men who cut a clearing in the gallery forest (which takes two to three months). The vegetation is then allowed to dry for at least a month before burning in very late August or September. This results in an intense fire, thoroughly clearing the area for planting. These fires can potentially be very dangerous, especially if it is windy on the day of the burn. Dry fuel around the roça is rarely cleared, and as a result fires occasionally burn into the adjoining vegetation. In order to reduce this possibility, most burns are set in the afternoon, when it is less windy. Dried palm leaves set alight with matches are used to ignite fuel at various points on the periphery of the roça and the fire is allowed to burn towards the middle of the plot and against the wind. Back fires are seen to be better because "it burns well, the ash stays on the ground and doesn't escape into the air" (Krahô informant).

Honey is an important resource and is collected in September and October. Fire is used in honey collection in two ways. If the hive is high on the tree, the tree is cut and palm leaves are used to burn around the fallen hive and smoke out the bees. In cases where the hive is not high on the tree, a fire is set beneath the tree to get smoke into the hive. Various villagers 
commented that fires for honey collection could sometimes become uncontrollable.

Some villagers, notobly in Santa Cruz, had small herds of cattle, and use delimitated areas of cerrado for pasture. Every year around mid-May an area is burned to provide fresh growth for the cattle.

"Some Wakmejê like to burn to keep the cerrado clean, so they can run, do the races" (Krahô informant). Increasing the visibility of the vegetation and landscape is an important element of burning for the Krahô-they feel that the cerrado has to be "renewed." They also perceive tall grass as "bad for walking," particularly because of dangerous or annoying animals such as snakes, scorpions, ticks, and wasps. These are usually hidden in tall grass, so burning the vegetation helps to eliminate or expose these potential hazards. Thick grass also impedes the speed of walking and running, and the main communication routes are regularly burned. Most Krahô agreed that the cerrado needs to be burned every 2-3 years so as to keep it "clean" and that the best time for "cleaning" was the late dry season.

\section{Krahô Perceptions of Fire}

Most villagers commented that fire is "good and bad at the same time." Many said that areas of cerrado need to be burned either early in the dry season so that burns later in the season do not get out of control, or every couple of years to prevent fuel build-up and consequently larger, more intense fires. Villagers remember catastrophic fire events, and these are retold through oral history reinforcing the importance of setting fires at the "right time." Most villagers interviewed agreed that the cerrado needs to be burned every 2-3 years, and that was the practice of the Krahô. For example, a Krahô elder, Feliciano Tephot Krahô, said:

\footnotetext{
I know a place here that had many deer, and I feel very sorry because it shouldn't have happened. Listen, passed four years drying, drying leaves, drying grass, drying everything. And when it was the dry time, the rains went away, and came the fire, came from I don't know where to this area, entered the forest, caught a bunch of very large buriti. Entered the marsh! Burned everything! It's because of this I don't like to leave a place for a lot of time without burning, because one day that fire arrives, you can't put it out. No-one can put out. It finishes everything. It can enter the forest, the marsh, the fire finishes.
}

Many Krahô mentioned a "reserve" in the centre of their territory which is protected from fire longer than other areas of cerrado. This place is thought to be the "source" of all natural resources, particularly animals, described by Feliciano Tephot Krahô:

This place is flat and very, very beautiful. It has lots of game, fish, rivers. Lots of game like anteaters and peccary, and you see many tracks of animals there. 
In terms of fire, it is burned at longer time intervals and then as a community:

\begin{abstract}
At times, four to five years pass that no-one goes there, except a hunter, to hunt deer, and at the time he passes there he sets fire, to clean, because if-I think this-if you leave a place, a space for a long time, it can catch fire and kill trees. It kills, it doesn't clean underneath... For the reserve to pass so long, five, six, seven or eight years [without fire], to then set fire a community goes, stay in a place around the locale and set fire. It is an enclosure of fire to kill the animals of fire. Deer, anteaters ... that there was inside. It is a lively ritual, and everyone returns animated. Only people that know, that don't tire easily to set fire in that area. It's only the adults that set fire and afterwards they arrive to collect the game that died there. (Feliciano Tephot Krahô)
\end{abstract}

Interestingly, many of the Krahô use the moon as an indicator of when to burn. However, it is only used when burns are related to agriculture. For example, the best time to burn roças or pastures is during the "crescente" (waxing moon) and "lua cheia" (full moon) periods, when the moon is to the north. The Krahô believe that fires during this phase of the lunar cycle will "burn more and better," be "strong" and produce a lot of ash as fertilizer. The grass regrowth is "rapid and clean," and there are no diseases that will affect the crops. If, on the other hand, burning takes place during the "miguante" (waning moon) when the moon is to the south, diseases will affect the crops grown on the land, and the grass that regrows will kill the cows. The Krahô who use the moon to determine fire timing also rely on it for timing other farming activities, including crop sowing and harvesting. For example, manioc, rice, and bananas are best planted during the full moon, whereas pumpkins and melons are best planted during the waning moon. Even villagers who themselves did not use the moon claimed that the moon was "important" and "controlled many things."

Overall, the Krahô perceive fire as an inherent part of their lives. This is clearly illustrated by their very permissive attitude towards children playing with fire. We observed children playing with fire in the centre of the villages and the surrounding areas nearly every night during the dry season, without their parents being in any way concerned. For example, a favorite pastime for children during the night was to run around with burning palm leaves. Sometimes we observed up to 20 children running with these torches inside the village, surrounded by thatched huts.

\title{
The Role of Women and Fire
}

Women play a very restricted role in the utilization of fire in the cerrado. For them, fire is more important with respect to their daily domestic duties. For example, the stove fire, or cuhy criré, is used for cooking 
main meals, normally three times per day, as well as for making drinks and snacks, such as coffee or tea. Another smaller type of fire, termed kiji criré, is used for heating during the nights, particularly in the dry season. During special occasions, the community cooks together a dish called paparuto (made of grated manioc and pieces of meat), and a special bonfire is made for this, termed méní kij catti méhohkêtcriré. Nevertheless, women do sometimes burn the cerrado. For example, women sometimes burn the land around their houses during the dry season to "clean" the area, as well as to eliminate pests. This cleansing burn is termed ahhihpôc, and women say they need to do it so that children and older people can walk around without worry. Some women also burn the cerrado when they go to collect fruits or honey:

I burned the cerrado when walking through because the grass was tall, I was collecting fruits, and I didn't want to get bitten by snakes... I've already seen this ... I burned when collecting honey, the fire kept going and I followed. (Krahô female elder)

Women may also sometimes help their husbands to burn the roças, although he normally instigates the burn. When looking at perceptions of fire, there are mixed views. Some women think fire is a good thing, and are not afraid of it, whereas others think fire is only good if used at the "right time."

\section{DISCUSSION}

\section{Fire Management Decision Making}

The process of decision making can be viewed in terms of three major variables - objectives, options, and perceptions (Norton and Walker, 1985). With regard to fire management decisions made by the Krahô, the main objectives are for cultivation, hunting, protection of resources, enhancement of resources, and "cleaning" the land, including increasing visibility in vegetation. These fire management objectives are comparable with those of other indigenous and traditional communities around the world. For example, traditional communities in the savannas of east-central Senegal point out land clearing and preparation, and hunting as two of the main reasons for setting fires (Mbow et al., 2000). Laris (2002), working in the savannas of Mali, shows that traditional farmers also burn to prepare fields for cultivation, but that here the most common reason for burning is to protect areas such as trees, orchards and agricultural fields from uncontrolled fire, or to prevent later, more damaging dry season fires. Protection through the use of fire is also important to the Aborigines living in the savannas of 
northern Australia. Conservation of plant food resources, including roots, flowers, and fruit, is managed through the manipulation of fire (Haynes, 1985; Russell-Smith et al., 1997a).

Honey gathering is an important subsistence activity in September and October, and fire is an integral component of the process. There are no recorded accounts of fire being used for honey collection by other indigenous groups, although it is obvious that fire is commonly used in traditional honey collecting methods for smoking out bees. However, the use of fire in gathering other natural resources has been described in some detail. For example, Boyd (1999) explains how fire was used by the Kalapuya Native Americans of the Pacific Northwest in the collection of subsistence foods such as tarweed, insects, and wild nuts and berries.

The "fire drive" for hunting is quoted by many indigenous cultures as a specific reason for burning vegetation. The Aborigines of Australia use this method for hunting large macropods (Haynes, 1985), whereas in North America, it was used specifically to hunt deer, termed the "circle deer hunt" (Boyd, 1999), and involved a burn around an area from which there is either no or only one escape route. Individual Krahô hunters also use this method, although the authors were informed that it is rare and only used by those considered to be expert hunters. In this case, natural boundaries in the landscape, such as rocks, are used to trap game, and fire is used only on one side of the enclosure. Fires are also set by the Krahô to promote "green pick" which will attract game to certain areas. Again, this is a common practice among indigenous groups, such as Native Americans and Australian Aborigines where "fire yards" or "fire corridors" are created by the selective use of fire in places where animals collect or traverse, thereby providing a higher measure of hunting predictability (Lewis and Ferguson, 1988).

Interestingly, the Krahô and Aborigines of northern Australia share the compulsion to "clean" the land, especially when travelling through the landscape. The Krahô find it difficult to explain the reason for doing this, although increasing visibility is part of the motive. Haynes (1985) captures this urge to burn, when he talks of Aboriginal "cleaning up":

This is regarded as being so important that the season is overlooked and intense fires have ensued... Informants are reluctant to discuss the purpose of "cleaning" in detail because they are unable to divulge some of the totemic/religious symbolism related to fire. It is sufficient to note here that to Aboriginal people "cleaning up" is just as important as, or more important than, the easily rationalized reasons [for burning]. (p. 210)

Apart from burning, it would seem there are no other options available to the Krahô to meet their objectives. Cost-benefit analysis of options available to small farmers in the savannas of central Brazil indicated that they did have other options apart from fire to meet their management 
objectives, although in the end the benefits of fire far outweighed the costs (Mistry, 1998b). For the Krahô, there are no realistic alternatives to burning for preparing roças, hunting, or protection of resources. For example, their income from casual labour, or artisan work would not be sufficient to allow them to hire tractors or buy fertilizers for their fields, nor to buy meat on a regular basis. For the protection of resources, the Krahô could potentially make firebreaks by eliminating vegetation around these resources, but the cost in terms of manual labour and time would not offset the ease of fire use.

Perceptions are the way certain ideas or knowledge are interpreted or understood, and play a large role in the fire decision-making process for the Krahô, and in many cases are the overriding factor behind certain fire management strategies. The most apparent perceptions are those governed by the differentiation of the Krahô into the two social groupings.

These perceptions have consequences on the types of fire that occur. In general, the fires organized by the Wakmejê are better managed. For example, many Wakmejê said that they always burned the areas around their roças earlier in the dry season (mid-May/June), to protect the surrounding forest from the fire. However, it was thought that Katamjê did not do this, and frequently allowed their fires to burn into the forest. In fact, the research team observed a fire set in a roça by a Katamjê which went out of control and burned at least $40 \mathrm{~m}$ into the surrounding forest. Although the Wakmejê burn the cerrado throughout the dry season, they are perceived to carry out their burnings in non-destructive ways.

The perception amongst the Krahô that the moon (pyt roré) controls fire was also found among small farmers of the cerrado in central Brazil (Mistry, 1998b), and interestingly there are similar beliefs in the two groups. Both the small farmers and the Krahô state that burning during the "crescente" (waxing moon) and "lua cheia" (full moon) periods, will produce "rapid and clean" regrowth/crop growth. Both groups also use the moon to determine other cultivation activities, including crop sowing and harvesting. The strong belief by the Krahô that the moon controls processes on the earth would suggest that the perception has been passed down from indigenous peoples through generations of cultural exchanges to present day farmers. However, we are uncertain of its origins, although it is a major factor affecting decision making.

\section{Impact of Changing Perceptions}

With the growing criticism from outsiders, notably farmers of European descent, on the extent of burning by the Krahô, perceptions are slowly changing. These criticisms are having their most significant impact 
in the group decision-making process led by the Wakmejê. Because discussions are public, during the morning meetings many younger Krahô men who have been influenced by outsiders openly criticize burning. As a result, many early season protective and resource enhancing fire practices are not implemented. On the other hand, because individuals are not under the scrutiny of the group, they continue to use fires. Unfortunately, these mostly happen in the late dry season (honey collection and burning of the roça), which is resulting in increasingly damaging late-season fires that only serve to reinforce citicisms against fire use.

There are many younger members of the Wakmejê group that claim they do not burn the cerrado nor advocate burning because it is bad for the environment. The Krahô of the younger generation are keen to learn and have contact with contemporary Brazilians, and it is only natural that ideas of locals, mainly farmers, will influence the behaviour of some of their number. However, this may be a source of future conflict—older members of the group already complain that youngsters are gradually losing their traditional knowledge, including that pertaining to fire management. If in the future the Krahô continue to decrease their burning, or change their burning strategies, and there is an increase in poachers coming into the reserve using fire in the late dry season, it seems likely that the impact of the new fire regimes will have an effect on vegetation patterns in the Krahô land and associated natural resources.

\section{Indigenous Burning: A Lesson in Patch Dynamics}

Recent studies indicate that indigenous people all over the world have used fire for thousands of years to carefully control and modify the landscapes in which they lived (Anderton, 1999; Boyd, 1999; Vale, 2002). This is in contrast to perceptions of traditional land management where native peoples are viewed to be proponents of an untouched environment. Native Americans and Australian Aborigines, for example, have modified their landscapes through the manipulation of the frequency, pattern, and extent of fires.

Omer Stewart, the first anthropologist to record in detail the phenomenon of native burning in North America lists the following reasons for burning:

Although fire is reported most frequently used to aid hunting - to encircle, to rouse, to stampede-fifteen other reasons for setting fires are given. These were as follows: to improve pasture, improve visibility, collect insects, increase yield of seeds, increase yield of berries, increase other wild vegetable foods, make vegetable food available, remove or thin trees to allow other growth, clear land for planting, stimulate growth of wild tobacco, aid in warfare, produce a spectacle, and reduce danger 
from snakes, insects, etc. Sheer carelessness, of course, is often reported as a cause of fire. (Stewart, 1953)

Some of these reasons for burning given by the Krahô and described in this study are shared with other indigenous groups, notably the Aborigines of Australia. The variety of objectives meant that fire was not an event that occurred during one time frame in the dry season. In fact, fire was used throughout the dry season, starting from the early dry season when grasses were cured sufficiently to burn but the climate and fuel conditions did not propagate large-scale fires. As the dry season progressed further fires were set, but although the climate and fuel conditions became more conducive to intensive fires, the previous small-scale fires had produced a mosaic of burned patches in the landscape that deterred larger fires from occurring, termed a "patch-mosaic fire regime" (Parr and Brockett, 1999). Native Americans used this strategy to keep the forests open, protect fruits, and prevent conflagrations (Anderton, 1999; Boyd, 1999; Vale, 2002), as did the Australian Aborigines (Haynes, 1985, 1991; Lewis, 1989; Russell-Smith et al., 1997a). Laris (2002) describes the spatio-temporal burning regime of local people in the savannas of Mali over the whole dry season. They employ early dry season fires to burn off as much dry grass as possible in order to prevent later fires from entering unwanted areas. In fact, of the people interviewed in his study, $74 \%$ of those that used fire cited the most common reason for burning as being to protect areas from fire or prevent later, damaging fires. As the savanna landscape is fragmented by early dry season fires, people can burn later in the dry season knowing that fires will be at least partially contained (Laris, 2002).

The Krahô also have a patch-mosaic fire regime correlated with the range of objectives for setting fires. Fires are set from the early dry season in April right through to September in the later part of the dry season. Some areas are left unburned for varying numbers of years, depending on the resource that is being managed and/or the cultural or spiritual significance of an area. This includes the "reserve" in the center of the territory, thought to be the source of all wild animals and plants, and areas of carrasco, again areas of vegetation thought to contain a higher diversity of natural resources. Over time this results in a landscape pattern comprised of patches in various stages of fire succession intermingled with unburned patches.

The benefits of producing a mosaic of patch types of differing fire histories within the landscape are twofold. First, as mentioned above, is the creation of natural firebreaks within the landscape to protect particular vegetation patches generating a landscape in which some patches burn regularly and others rarely burn (Laris, 2002). The second benefit may be 
the maintenance and enrichment of biodiversity through the creation and preservation of a variety of microhabitats that support different species. Braithwaite (1996), for example, argues that the present biodiversity in the northern Australian savanna was maintained by an historic Aboriginal fire regime which produced a mosaic of patches. In the South African savannas, fine-scale mosaics shaped by fire also enhance the abundance and diversity of vertebrate fauna (Mentis, 1978; Mentis and Bigalke, 1981; Rowe-Rowe and Lowry, 1982).

\section{Policy Implications of Indigenous Burning}

The correct and effective use of fire for managing areas of cerrado could bring about many environmental benefits. These include stimulating certain plant species to sprout, flower, fruit, or set seed, increase the vigour and palatability of particular herbaceous species, enhance nutrient recycling, control invasive species, maintain biodiversity, and consume accumulated fuels and so prevent the spread of wildfires. Nevertheless, the various perceptions and misconceptions about the effects of fire on natural ecosystems, popularized largely by cases of wildfires in fire-sensitive ecosystems such as tropical lowland forests, has led government sectors in Brazil to deter fires in the cerrado (a fire-adapted ecosystem), whether they be natural or prescribed. In conservation areas, environmental legislation has allowed the use of fire since 1989 for managing nature reserves (Federal Decree No. 97635 of April 10, 1989), but in reality few government officials permit these to take place. Brazilian law also acknowledges the necessity of fire for agricultural purposes (Ministerial Decree $\mathrm{N}^{\circ}$ 229/75 of May 7, 1975), but prescribed burns can only take place according to rules set out in Article 27 of Federal Law $\mathrm{N}^{\circ} 4.771$ of September 15, 1965. These rules and regulations are elaborate, complicated, and costly, and as shown by Mistry (1998b), either unknown or not considered at all in decision making by many farmers.

The consequences of a lack of an adequate fire management policy in the Brazilian cerrado have been twofold. The occurrence of numerous devastating wildfires in the cerrado regularly hit the media headlines. In some national parks, such as Emas National Park, severe fires occur every 3-4 years-between 1973 and 1995, 74-93\% of the 132,133 ha park burned (França and Setzer, 1997). The second outcome of the present fire management stance is the illegal, and sometimes inappropriate, burning of the cerrado for agricultural purposes.

Although there is a growing wealth of knowledge on the ecological role of fire and it's impact in the cerrado (Mistry, 1998a), there is still a 
crucial need for information on how different people use fire and their fire practices, vital for informing policymakers. For example, Mistry (1998b) has described the traditional fire management regime of small farmers in the cerrado, predominantly for agricultural purposes. Indigenous people, as illustrated by this study of the Krahô, normally burn for a greater variety of objectives and over larger areas, and thus, information regarding their burning regimes is more pertinent to the management of conservation areas such as national parks.

The use of a patch-mosaic burning strategy in cerrado conservation areas would help prevent the spread of wildfires and promote biodiversity of both the floral and faunal components. The view that indigenous burning benefits savanna ecosystems is gaining growing acceptance among land managers, notably in Australia and South Africa. In Australia, detailed accounts of Aboriginal burning have resulted in new programs to establish Aboriginal burning regimes in national parks, such as Kakadu (RussellSmith, 1995; Russell-Smith et al., 1997b) and Uluru (Saxon, 1984). Brockett et al. (2001) describe a patch-mosaic burning system and its application in the Pilanesberg National Park, South Africa. In all of these cases, early dry season burning is seen as critical because the weather and fuel conditions result in smaller, patchier fires. As the dry season progresses, the spatial and behavioral nature of fires are limited by previous burns, ultimately producing a heterogeneous landscape.

In Brazil, the adoption of indigenous burning regimes, similar to the Krahô, seems unlikely until it is recognized by policymakers that there is an urgent need for some form of fire management in the cerrado reflecting the growing body of evidence against fire protection. Nonetheless, the need to understand why, when, and how people burn is of utmost importance, and as this study indicates, the documentation of traditional burning regimes of indigenous peoples is of significance for contemporary conservation and management.

\section{CONCLUSIONS}

The paradigm shift from equilibrium dynamics to a disequilibrium view of savanna functioning suggests that disturbances, such as fire, may generate and sustain the coexistence of trees and grasses through the development of heterogeneity (e.g., Jeltsch et al., 1998, 2000). It seems that the Krahô methods of fire management adhere to this principle through the creation of a mosaic of patches in the landscape. Further research is now being carried out to investigate the consequences of this management practice on vegetation distribution by comparing satellite images over two decades. 
Preliminary results show that key vegetation types, such as gallery forests, have remained relatively intact within the Krahô reserve while a significant reduction is apparent outside the reserve.

Nevertheless, the tide seems to be turning: more and more fire decisions are being made by individuals, rather than as a group; and Krahô fire knowledge is being lost. The Brazilian government has put major development efforts into the region, and the Tocantíns is now one of the agricultural frontiers for soybean and cattle production (Théry, 2002). To export this produce, infrastructural developments, chiefly the paving of major roads, are planned for the region. These advances are moving ever closer to the Krahô, and have significant implications for their livelihoods and landscape management practices. Foremost will be the potential conflicts over natural resources such as water, trees, and game. As more people surround and invade Krahô land, the pressures on the Krahô to abandon their traditional management practices will be significant, risking permanent loss of their culture and their environment. Official acceptance of indigenous landscape management practices for conserving the remaining areas of Brazilian cerrado may not only protect biodiversity and other valuable natural resources, but may give indigenous people the confidence and influence to retain their traditional culture.

\section{ACKNOWLEDGMENTS}

Foremost we thank the Krahô for their help and participation in the research, and for their acceptance of us into their world. We gratefully acknowledge the Conselho Nacional de Desenvolvimento Científico e Tecnológico (CNPq) and the Fundação Nacional do Indio (FUNAI) for permissions, and the National Geographic for funding and supporting the research. Big thanks to Txicaprô Krahô and Phocrok Krahô for their invaluable help with the fieldwork. Thanks also to the two anonymous referees for their positive comments. And finally, to those that helped in lots of different ways: Fernando Schiavini, Ulysses Monteiro, Milton Filho, Jomar, Maricy Marino, and Dulce Rocha.

\section{REFERENCES}

Alexandre, A., Meunier, J. D., Mariotti, A., and Soubies, F. (1999). Late Holocene phytolith and carbon-isotope record from a latosol at Salitre, south-central Brazil. Quaternary Research 51: 187-194.

Anderson, A. B., and Posey, D. A. (1985). Manejo de cerrado pelos indios Kayapó. Boletim do Museu Paraense Emilio Goeldi Botânica 2(1): 77-98.

Anderson, A. B., and Posey, D. A. (1989). Management of a tropical scrub savanna by the Gorotire Kayapó of Brazil. Advances in Economic Botany 7: 159-173. 
Anderton, J. B. (1999). Native American, fire-maintained blueberry patches in the coastal pine forests of the northern Great Lakes. The Great Lakes Geographer 6(1/2): 29-39.

Balée, W. (1994). Footprints of the Forest. Ka'apor Ethnobotany-The Historical Ecology of Plant Utilization by an Amazonian People, Columbia University Press, New York.

Barberi, M., Salgado-Labouriau, M. L., and Suguio, K. (2000). Paleovegetation and paleoclimate of "Vereda de Aguas Emendadas," central Brazil. Journal of South American Earth Science 13(3): 241-254.

Barbosa, A. S. (2002). Andarilhos da Claridade: os primeiros habitantes do Cerrado, Universidade Católica/Instituto Trópico Subúmido, Goiânia.

Behling, H. (1995). A high-resolution Holocene pollen record from Lago do Pires, SE Brazilvegetation, climate and fire history. Journal of Paleolimnology 14 (3): 253-268.

Behling, H. (1998). Late Quaternary vegetational and climatic changes in Brazil. Review of Palaeobotany and Palynology 99: 143-156.

Behling, H. (2002). South and southeast Brazilian grasslands during Late Quaternary times: A synthesis. Palaeogeography, Palaeoclimatology, Palaeoecology 177(1-2): 19-27.

Boyd, R. (1999). Strategies of Indian burning in the Willamette Valley. In Boyd, R. (ed.), Indians, Fire and the Land in the Pacific Northwest, Oregon State University Press, Corvallis.

Braithwaite, R. W. (1996). Biodiversity and fire in the savanna landscape. In Solbrig, O. T., Medina, E., and Silva, J. (eds.), Biodiversity and Savanna Ecosystem Processes, Springer, Berlin.

Brockett, B. H., Biggs, H. C., and van Wilgen, B. W. (2001). A patch mosaic burning system for conservation areas in southern African savannas. International Journal of Wildland Fire 10: $169-183$.

Dawson, S., Manderson, L., and Tallo, V. L. (1993). A Manual for the Use of Focus Groups, International Nutrition Foundation for Developing Countries, Boston.

Dewalt, K., Dewalt, B., and Wayland, C. (1998). Participant observation. In Bernard, H. (ed.), Handbook of Methods in Cultural Anthropology, Alta Mira, Walnut Creek, CA.

França, H., and Setzer, A. (1997). Regime de queimadas no Parque Nacional das Emas, GO: 1973-1995 (Relatório de pesquisa), I.N.P.E.-D.S.R., São José dos Campos, SP.

Geertz, C. (1983). Local Knowledge: Further Essays in Interpretive Anthropology, Basic Books, New York.

Giaccaria, B., and Heide, A. (1984). Xavante: Povo autêntico, Editora Salesiana Dom Bosco, São Paulo.

Hall, J., McLeod, R. A., and Mitchell, V. (1987). Pequeno Dicionário Xavante/Português e Português/Xavante, Summer Institute of Linguistics, Brazil.

Haynes, C. D. (1985). The pattern and ecology of munwag: Traditional Aboriginal fire regimes in north-central Arnhemland. Proceedings of the Ecological Society of Australia 13: 203214.

Haynes, C. D. (1991). Use and impact of fire. In Haynes, C. D., Ridpath, M. G., and Williams, M. A. J. (eds.), Monsoonal Australia: Landscape, Ecology and Man in the Northern Lowlands, A.A. Balkema, Rotterdam.

Hecht, S., and Posey, D. A. (1989). Preliminary results on soil management techniques of the Kayapó Indians. Advances in Economic Botany 7: 174-188.

Jeltsch, F., Milton, S. J., Dean, W. R. J., van Rooyen, N., and Moloney, K. A. (1998). Modelling the impact of small-scale heterogeneities on tree-grass coexistence in semi-arid savannas. Journal of Ecology 86: 780-793.

Jeltsch, F., Weber, G. E., and Grimm, V. (2000). Ecological buffering mechanisms in savannas: A unifying theory of long-term tree-grass coexistence. Plant Ecology 161: 161-171.

Kerr, W. E., and Posey, D. A. (1984). Notas sobre a agricultura dos indios Kayapo. Interciencia 9(6): 392-400.

Krueger, R. A. (1994). A Practical Guide for Applied Research, Sage, Thousand Oaks.

Laris, P. (2002). Burning the seasonal mosaic: Preventative burning strategies in the wooded savanna of southern Mali. Human Ecology 30(2): 155-186.

Lavallée, D. (1995). The First South Americans. The peopling of a Continent From the Earliest Evidence to High Culture, The University of Utah Press, Salt Lake City. 
Levy, R. I., and Hollan, D. W. (1998). Person-centred interviewing and observation. In Bernard, H. (ed.), Handbook of Methods in Cultural Anthropology, Alta Mira, Walnut Creek, CA.

Lewis, H. T. (1989). Ecological and technological knowledge of fire: Aborigines versus park rangers in Northern Australia. American Anthropologist 91: 940-961.

Lewis, H. T., and Ferguson, T. A. (1988). Yards, corridors and mosaics: How to burn a boreal forest. Human Ecology 16: 57-77.

Lukesch, A. (1969). Mito e vida dos indios Caiapós, Editora da Universidade de São Paulo, São Paulo.

Maybury-Lewis, D. (1984). A sociedade Xavante, Francisco Alves, Rio de Janeiro.

Mbow, C., Nielson, T. T., and Rasmussen, K. (2000). Savanna fires in east-central Senegal: Distribution patterns, resource management and perceptions. Human Ecology 28(4): 561583.

McLeod, R., and Mitchell, V. (1980). Aspectos da Lingua Xavante. Summer Institute of Linguistics, Brazil.

Melatti, J. C. (1972). O Messianismo Krahô, Héder USP, São Paulo, Brazil.

Melatti, J. C. (1986). Índios do Brasil, HUCITEC, Universidade de Brasília, São Paulo.

Mentis, M. T. (1978). Population limitation in grey rhebuck and oribi in the Natal Drakensberg. The Lammergeyer 26: 19-28.

Mentis, M. T., and Bigalke, R. C. (1981). The effect of scale of burn on the densities of grassland francolins in the Natal Drakensberg. Biological Conservation 21: 247-261.

Miranda, H. S., Bustamante, M. M. C., and Miranda, A. C. (2002). The fire factor. In Oliveira, P. S., and Marquis, R. J. (eds.), The cerrados of Brazil. Ecology and natural history of a neotropical savanna, Columbia University Press, New York.

Mistry, J. (1998a). Fire in the cerrado (Savannas) of Brazil: An ecological review. Progress in Physical Geography 22: 425-448.

Mistry, J. (1998b). Decision-making for fire use among farmers in the savannas of central Brazil. Journal of Environmental Management 54: 321-334.

Nimuendajú, C. (1983). Os Apinayé, Museu Paraense Emilio Goeldi (tradução da edição inglesa de 1939), Belém.

Norton, G. A., and Walker, B. H. (1985). A decision analysis approach to savanna management. Journal of Environmental Management 21: 15-31.

Parr, C. L., and Brockett, B. H. (1999). Patch-mosaic burning: A new paradigm for savanna fire management in protected areas? Koedoe 42: 117-130.

Posey, D. A. (1992). Interpreting and applying the "reality" of indigenous concepts: What is necessary to learn from the natives? In Redford, K. H., and Padoch, C. (eds.), Conservation of Neotropical Forests. Working From Traditional Resource Use, Cambridge University Press, New York.

Posey, D. A. (1998). Diachronic ecotones and anthropogenic landscapes in Amazonia: Contesting the consciousness of conservation. In Balée, W. (ed.), Advances in Historical Ecology, Columbia University Press, New York.

Pyne, S. J. (2001). Fire. A brief history, The British Museum Press, London.

Rowe-Rowe, D. T., and Lowry, P. B. (1982). Influence of fire on small-mammal populations in the Natal Drakensberg. South African Journal of Wildlife Research 16: 32-35.

Russell-Smith, J. (1995). Fire management. In Press, T., Lea, D., Webb, A., and Graham, A. (eds.), Kakadu. Natural and Cultural Heritage and Management, Australian Nature Conservation Agency, North Australia Research Unit, The Australian National University, Darwin.

Russell-Smith, J., Lucas, D., Gapindi, M., Gunbunuka, B., Kapirigi, N., Namingum, G., Lucas, K., Giuliani, P., and Chaloupka, G. (1997a). Aboriginal resource utilisation and fire management practice in western Arnhem Land, monsoonal northern Australia: Notes for prehistory, lessons for the future. Human Ecology 25(2): 159-195.

Russell-Smith, J., Ryan, P. G., and Durieu, R. (1997b). A LANDSAT MSS-derived fire history of Kakadu National Park, monsoonal northern Australia, 1980-94: Seasonal extent, frequency and patchiness. Journal of Applied Ecology 34: 748-766. 
Salgado-Labouriau, M. L., Barberi, M., Ferraz-Vicentini, K. R., and Parizzi, M. G. (1998). A dry climatic event during the late Quaternary of tropical Brazil. Review of Palaeobotany and Palynology 99: 115-129.

Saxon, E. C. (1984). Anticipating the inevitable: A patch-burn strategy for fire management at Uluru (Ayers Rock-Mt Olga) National Park, CSIRO Division of Wildlife and Rangelands Research, Melbourne.

Stewart, O. (1953). Why the Great Plains are treeless. Colorado Quarterly 2(1): 40-50.

Théry, H. (2002). Novas fronteiras na Amazônia, Paper presented at the Cruzando fronteras en América Latina, Tercer Congreso de Latinoamericanistas, Amsterdam 3-6 July 2002.

Vale, T. R. (Ed.). (2002). Fire, native peoples and the natural landscape, Island Press, Washington.

Vernet, J. L., Wengler, L., Solari, M. E., Ceccantini, G., Fournier, M., Ledru, M. P., and Soubies, F. (1994). Fire, climate and vegetation in central Brazil during the HoloceneData from a soil profile with charcoal (Salitre, Minas Gerais). Comptes Rendus de $l$ Academie des Sciences Serie II 319 (11,2): 1391-1397.

Villas-Boas, O., and Villas-Boas, C. (1976). Xingu—Os indios, Seus Mitos, Zahar Editores, Rio de Janeiro.

Watanabe, S., Ayta, W. E. F., and Hamaguchi, H. (2003). Some evidence of a date of first humans to arrive in Brazil. Journal of Archaeological Science 30: 351-354. 